\title{
Evidence for a systemic role for ovarian oxytocin in luteal regression in sheep
}

\author{
A. P. F. Flint and E. L. Sheldrick \\ A.R.C. Institute of Animal Physiology, Babraham, Cambridge CB2 4AT, U.K.
}

\begin{abstract}
Summary. Jugular venous concentrations of oxytocin and progesterone changed in parallel during the oestrous cycle in the ewe, falling at luteal regression and rising with formation of the new corpus luteum. These fluctuations in the circulating concentration of oxytocin were not caused by changes in its metabolic clearance rate. On Days 6-9 of the cycle circulating oxytocin concentrations exhibited a diurnal rhythm, peaking at $09: 00 \mathrm{~h}$; this rhythm was absent on Days 11-14. Although there was no evidence for increased production of oxytocin at or preceding luteal regression in samples taken daily, more frequent sampling revealed that two thirds of detected surges of uterine secretion of prostaglandin (PG) F-2 $\alpha$ were accompanied by raised levels of oxytocin. This oxytocin was not of pituitary origin. Luteal regression induced with cloprostenol on Day 8 after oestrus caused a decrease in circulating progesterone level followed after $24 \mathrm{~h}$ by a fall in oxytocin. Measurements of oxytocin in the ovary and other organs before and after treatment with cloprostenol identified the corpora lutea as a major potential source of oxytocin, and suggested that $98 \%$ of luteal oxytocin was available for secretion in response to prostaglandin stimulation. The data are consistent with a role for ovarian secretion of oxytocin in response to uterine release of PGF- $2 \alpha$ in the control of luteal regression.
\end{abstract}

\section{Introduction}

The corpora lutea in sheep contain high concentrations of oxytocin (Wathes \& Swann, 1982) and secrete it into the ovarian vein (Flint \& Sheldrick, 1982), thereby presumably contributing to the relatively high levels of oxytocin in the circulation during the luteal phase of the oestrous cycle (Webb, Mitchell, Falconer \& Robinson, 1981; Sheldrick \& Flint, 1981 ; Schams, Lahlou-Kassi \& Glatzel, 1982a). Active immunization against oxytocin prolongs the luteal phase of the cycle (Sheldrick, Mitchell \& Flint, 1980; Schams, Prokopp \& Schmidt-Adamopoulou, 1982b) and oxytocin may therefore be involved in luteal regression. Such an involvement may be systemic as well as local; systemic administration of oxytocin releases prostaglandin (PG) F- $2 \alpha$ (which is luteolytic) from the uterus (Mitchell, Flint \& Turnbull, 1975; Roberts, McCracken, Gavagan \& Soloff, 1976; McCracken, Schramm, Barcikowski \& Wilson, 1981) and oxytocin has direct inhibitory effects on gonadotrophin-stimulated steroid synthesis in isolated ovarian and testicular cells (Tan, Tweedale \& Biggs, 1981a, b; Adashi \& Hsueh, 1981). If the action of oxytocin is exerted systemically, then it should be possible to demonstrate raised plasma concentrations of oxytocin at luteal regression; on the other hand, if its action is solely intraovarian there may be no increased secretion into blood at this time. The present experiments were undertaken to examine in detail the temporal relationships between changing concentrations of oxytocin and progesterone at spontaneous and induced luteal regression, with a view to assessing both the contribution made by 
the ovary to circulating oxytocin concentrations and the possibility of a systemic involvement of ovarian oxytocin in luteal regression.

\section{Materials and Methods}

\section{Animals}

The animals were taken from a flock of parous Clun Forest ewes which were kept in a paddock with a raddle-bearing vasectomized ram to determine mating dates. All ewes were cycling spontaneously during the breeding season; none received treatment to synchronize or induce oestrous cyclicity. In the season in which the experiments took place each animal had at least 2 normal oestrous cycles before being used. The mean cycle length for the flock was $16.5 \pm 0.1$ days $(n=63)$.

For taking daily blood samples, 17 ewes were brought into a yard, usually between $14: 00$ and $16: 00 \mathrm{~h}$, and $10 \mathrm{ml}$ blood were taken from a jugular vein by percutaneous venepuncture into a heparinized syringe. For taking blood samples at 2 -h intervals, and for determination of the metabolic clearance rate (MCR) of oxytocin, 15 ewes at known stages of the oestrous cycle were prepared with indwelling catheters inserted into the external jugular vein under local anaesthesia (Seldinger, 1953); for sampling only, 1 catheter was inserted, but for determination of MCR, 2 were required, one in each jugular vein. Because little is known of factors influencing secretion of oxytocin from the posterior pituitary or the ovary, care was taken to disturb the animals as little as possible by changes in lighting or temperature or by excessive handling during periods of frequent sampling. Therefore ewes to be sampled were kept in metabolism cages in an open shelter adjacent to the laboratory with no artificial heating or lighting. A vasectomized ram housed with the ewes provided the olfactory stimulus to which they were accustomed in the paddock. The shelter was separated from the laboratory by a light-proof door. Catheters were extended sufficiently to allow them to be brought into an adjoining laboratory through apertures in the intervening wall, thereby permitting samples to be taken without disturbing the animals. For checking behavioural oestrus the catheters were disconnected from their extensions and the ewes let out of the cages to run with a vasectomized ram once daily between samples, usually between 15:15 and 16:45 h. While in metabolism cages the ewes were fed chopped hay and water ad libitum plus $250 \mathrm{~g}$ concentrates/day.

For collection of jugular, ovarian and/or utero-ovarian venous plasma, 3 ewes at known stages of the oestrous cycle were anaesthetized with pentobarbitone sodium; after endotracheal intubation anaesthesia was maintained with halothane $/ \mathrm{O}_{2}$. Following insertion of a jugular venous catheter the uterus and ovaries were exposed by a mid-line incision and polyvinyl catheters $(0.97 \times$ $1.27 \mathrm{~mm}$; Dural Plastics, Dural, New South Wales, Australia) were inserted into an ovarian vein, a utero-ovarian vein, or both. The ovarian vein catheter was inserted within $2 \mathrm{~cm}$ of the ovary, with the catheter passed towards the ovary; catheters in utero-ovarian veins were inserted down-stream and passed away from the ovary. To permit collection of arterial blood, a catheter was inserted into the femoral artery, or into a branch of the uterine artery contralateral to the uterine venous catheter. Blood samples were taken when possible at 10, 5 and $1 \mathrm{~min}$ before, and 2, 5, 10, 15, 20, 30 and $40 \mathrm{~min}$ after administration of cloprostenol (Estrumate: I.C.I. 80996), $125 \mu \mathrm{g}$ i.m., in a single site.

Jugular venous blood samples were also collected from a further 2 ewes which had been ovariectomized 16 weeks earlier. These animals were catheterized under local anaesthesia. After centrifugation plasma was stored in $2 \times 1 \mathrm{ml}$ aliquants in oxytocin extraction tubes (capped polystyrene tubes, $12 \times 75 \mathrm{~mm}$ ) and in separate plastic blood collection tubes (up to $5 \mathrm{ml}$ ) at $-20^{\circ} \mathrm{C}$.

\section{Metabolic clearance rates}

Metabolic clearance rate (MCR) of oxytocin was measured by a method similar to that described by Dawood, Ylikorkala, Trivedi \& Gupta (1980). A solution of oxytocin (Oxytocin Leo: 
Leo Laboratories, Princes Risborough, Bucks) in sterile saline $(9 \mathrm{~g} \mathrm{NaCl} / 1)$ was infused into one jugular vein in 7 animals which were on the day of oestrus (Day 0) or on Day 10 of the oestrous cycle. Blood samples were collected from the contralateral jugular vein. After collecting 3 pre-infusion samples blood was taken at 5-min intervals during a 37-min infusion. Oxytocin was measured in all blood samples. A constant circulating concentration of oxytocin (in the range $300-500 \mathrm{pg} / \mathrm{ml}$ ) was consistently reached within 25 min of the start of infusion, and blood samples taken at 25,30 and 35 min after the start of infusion were used to calculate MCR. The pre-infusion plasma concentration of oxytocin was subtracted from these values in the calculation. The concentration of oxytocin in the infusates was measured for each infusion, and infusion rates ranged from $62 \cdot 2$ to $146.9 \mathrm{ng} / \mathrm{min}$. Metabolic clearance rates were not related to the circulating concentrations of oxytocin reached, and therefore were apparently unaffected by the relatively high infusion rate. Similar findings have been made in man (Fabian, Forsling, Jones \& Pyror, 1969).

\section{Extraction of oxytocin from tissue samples}

Samples of corpora lutea and other tissues were collected from anaesthetized sheep treated with cloprostenol as well as from a number of other untreated ewes at autopsy. Tissues to be extracted for assay of oxytocin $(0 \cdot 2-1 \cdot 5 \mathrm{~g})$ were homogenized in $10 \mathrm{ml} \mathrm{1} \%$ acetic acid, after addition of $\left[{ }^{3} \mathrm{H}\right]-$ propionyl oxytocin $(80000$ d.p.m.) to allow calculation of recoveries. Homogenates were centrifuged at $10000 \mathrm{~g}$ for $30 \mathrm{~min}$ at $4^{\circ} \mathrm{C}$ and the supernatants freeze-dried. The residues were reconstituted in $5 \mathrm{ml}$ distilled water and centrifuged at $10000 \mathrm{~g}$ for $30 \mathrm{~min}$ at $4^{\circ} \mathrm{C}$. Supernatants were then stored at $-20^{\circ} \mathrm{C}$ until assayed.

\section{Radioimmunoassays}

Plasma samples. Progesterone, 13,14-dihydro-15-keto-PGF-2 $\alpha$ and oxytocin were measured by radioimmunoassays reported previously (Mitchell et al., 1976; Sheldrick et al., 1980; Sheldrick \& Flint, 1981). For the progesterone assay the sensitivity (calculated from $2 \times$ s.d. below the zerobinding point), intra- and inter-assay coefficients of variation and extraction recovery were $0 \cdot 12$ $\mathrm{ng} / \mathrm{ml}, 12.6 \%, 15 \cdot 0 \%$ (at $100 \mathrm{pg} /$ tube) and $88.7 \%$, respectively, for the assays reported in this paper. For the 13,14-dihydro-15-keto-PGF- $2 \alpha$ assays these values were: $14 \mathrm{pg} / \mathrm{ml}, 8 \cdot 4 \%, 8.4 \%$ (at 25 $\mathrm{pg} /$ tube) and $80 \cdot 6 \%$, and for oxytocin, $2.48 \mathrm{pg} / \mathrm{ml}, 9 \cdot 4 \%, 15 \cdot 7 \%$ (at $10 \mathrm{pg} /$ tube) and $80.6 \%$. Extraction recoveries were taken into account in calculating concentrations.

Since the description of the oxytocin radioimmunoassay (Sheldrick et al., 1980; Sheldrick \& Flint, 1981) several additional substances have been tested for ability to cross-react with the antiserum. The following is a list of compounds tested to date $(\%$ cross-reactions relative to oxytocin, determined at $50 \%$ displacement of tracer): 1,6-asulpho-oxytocin, $49 \cdot 6$; propionyl oxytocin, 48.9; mesotocin ([ $\left.{ }^{8} \mathrm{Ile}\right]$ oxytocin), $4 \cdot 1$; isotocin $\left(\left[{ }^{4} \mathrm{Ser},{ }^{8} \mathrm{Ile}\right]\right.$ oxytocin $),<1.0 \%$; arginine vasotocin ([ $\left.{ }^{8} \mathrm{Arg}\right]$ oxytocin), arginine vasopressin $\left(\left[{ }^{3} \mathrm{Phe},{ }^{8} \mathrm{Arg}\right]\right.$ oxytocin), lysine vasopressin ([ ${ }^{3}$ Phe, ${ }^{8}$ Lys]oxytocin), LH-RH, TRH, somatostatin, synthetic 1-24 ACTH, ovine LH (NIH-S17), ovine FSH (NIH-S6), ovine prolactin (NIH-S9), progesterone and melatonin, $<0.02 \%$; Pro-LeuGly- $\mathrm{NH}_{2}$ (7-9 oxytocin, putative $\mathrm{MSH}$ inhibitory factor) and cloprostenol, $<0.01 \%$.

Tissue extracts. Oxytocin was measured in tissue extracts by direct radioimmunoassay of reconstituted extracts $(50 \mu \mathrm{l})$ in triplicate. Dilutions of the extracts were prepared and crossreactivity measured in parallel to oxytocin standards. Tissue concentrations were corrected for procedural losses based on recovery of $\left[{ }^{3} \mathrm{H}\right]$ propionyl oxytocin in the final extract; mean \pm s.e.m. recovery was $70 \cdot 95 \% \pm 2 \cdot 13(n=29)$.

\section{Preparation of $\left[{ }^{3} H\right]$ propionyl oxytocin}

$N$-Succinimidyl[2,3-3 $\mathrm{H}]$ propionate $(1 \mathrm{mCi}, \mathrm{sp}$. act. $41 \mathrm{Ci} / \mathrm{mmol}$; The Radiochemical Centre, Amersham, Bucks) evaporated to dryness in a conical glass tube under $\mathrm{N}_{2}$, was dissolved in $12 \mu \mathrm{l}$ 
$0.1 \mathrm{M}$-sodium borate, pH 8.5 containing $6 \mu \mathrm{g}$ oxytocin (Bachem Inc., Torrance, California). After vortex mixing the solution was kept at room temperature for $1 \mathrm{~h}$. To separate reaction products ( $\left[{ }^{3} \mathrm{H}\right]$ propionic acid, $\left[{ }^{3} \mathrm{H}\right]$ propionyl oxytocin and unreacted oxytocin) the mixture was applied to a $17.5 \times 0.5 \mathrm{~cm}$ column of DEAE-Sephadex A-50 equilibrated in $25 \mathrm{~mm}$-sodium borate, pH 8.5. Unreacted oxytocin and $\left[{ }^{3} \mathrm{H}\right]$ propionyl oxytocin were recovered in the first $10 \mathrm{ml}$ eluate, separated from $\left[{ }^{3} \mathrm{H}\right]$ propionate. To separate $\left[{ }^{3} \mathrm{H}\right]$ propionyl oxytocin from unreacted oxytocin, $500 \mu \mathrm{l}$ aliquants of DEAE-Sephadex eluate were subsequently applied to $17.5 \times 0.5 \mathrm{~cm}$ columns of Sephadex CM-50 and eluted with $25 \mathrm{~mm}$-sodium acetate, $\mathrm{pH} 4 \cdot 0$. Elution volumes were 4-6 $\mathrm{ml}$ for $\left[{ }^{3} \mathrm{H}\right]$ propionyl oxytocin and $10-15 \mathrm{ml}$ for unlabelled oxytocin, and no detectable unlabelled oxytocin was eluted with the ${ }^{3} \mathrm{H}$-labelled product. Purified $\left[{ }^{3} \mathrm{H}\right]$ propionyl oxytocin stored at $\mathrm{pH} \mathrm{4 \cdot 0}$ at $4^{\circ} \mathrm{C}$ was stable for at least 1 year.

\section{Results}

Mean jugular venous concentrations of oxytocin and progesterone declined simultaneously before oestrus in plasma samples obtained daily and subsequently increased in parallel after formation of the new corpus luteum (Text-fig. 1). The decline in the circulating oxytocin concentration, which was less marked than that in progesterone, could not be accounted for by a change in metabolic clearance rate (MCR); the mean ( \pm s.e.m.) MCR for oxytocin was $300 \pm 40 \mathrm{ml} / \mathrm{min}(4.41 \pm 0.59$ $\mathrm{ml} / \mathrm{min} / \mathrm{kg}$ body wt) at Day 10 after oestrus ( 4 sheep) and $217 \pm 20 \mathrm{ml} / \mathrm{min}(3.85 \pm 0.81 \mathrm{ml} / \mathrm{min} / \mathrm{kg}$, 3 sheep) on the day of oestrus (difference, $P>0 \cdot 1$ ).

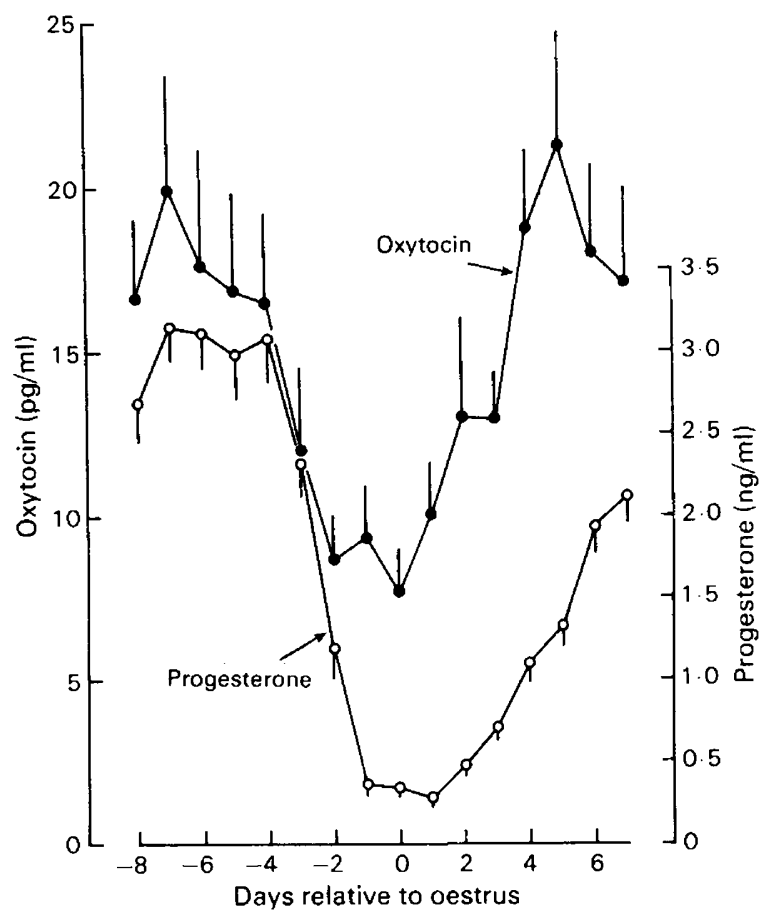

Text-fig. 1. Concentrations of oxytocin $(O)$ and progesterone $(O)$ in plasma samples taken from a jugular vein once per day (usually between 14:00 and 16:00 h). Values are mean \pm s.e.m. for 2 cycles from each of 17 ewes, plotted with reference to the day on which behavioural oestrus was noted (mating with a vasectomized ram). 
Episodic increases in circulating concentrations of oxytocin and 13,14-dihydro-15-ketoprostaglandin F-2 $\alpha$ were detectable when jugular venous samples were obtained at $2-\mathrm{h}$ intervals between Days 11 and 16 of the cycle (Text-fig. 2). These surges were presumably either missed, or were obscured in the process of calculating mean levels, in samples taken daily. Of all detected episodes of release of PGF- $2 \alpha$ (reflected in peaks of 13,14-dihydro-15-keto-PGF-2 $\alpha$ ), $35 \%$ were accompanied by raised concentrations of oxytocin; however, if only those surges were considered which occurred before the completion of luteal regression this proportion increased to $67 \%(2 / 2$ coincident surges in each of 3 animals, and $0 / 3$ in the fourth). Oxytocin concentrations declined before oestrus in all 4 animals.

To determine whether uterine release of PGF- $2 \alpha$ was likely to result in pituitary secretion of oxytocin, 5 ewes prepared with femoral arterial, jugular venous, ovarian venous or utero-ovarian venous catheters, were treated with cloprostenol (Table 1). Two of these animals, which were ovariectomized, were not anaesthetized. In no case was there detectable secretion of oxytocin into the jugular vein, as indicated by a difference between arterial and jugular venous concentrations, although cloprostenol stimulated secretion into the ovarian and utero-ovarian veins (Flint $\&$ Sheldrick, 1982). To investigate whether other ovarian or uterine tissues also secrete oxytocin during the oestrous cycle, extracts of a variety of such tissues were assayed for oxytocin content (Table 2). High concentrations of oxytocin were found only in extracts of corpora lutea, and these gave displacement curves which were parallel to those obtained with oxytocin standards when serial dilutions were measured by radioimmunoassay (data not shown).

Circulating concentrations of oxytocin and progesterone in sheep in which luteal regression was induced with cloprostenol are shown in Text-fig. 3. As there was no episodic release of oxytocin at this stage of the cycle, mean values ( \pm s.e.m.) are presented. Cloprostenol caused a rapid decline in plasma progesterone, and a brief increase in circulating oxytocin. There was no increase in jugular venous 13,14-dihydro-15-keto-PGF-2 $\alpha$ after administration of cloprostenol (data not shown).

Table 1. Secretion of oxytocin into the ovarian, utero-ovarian or external jugular veins of sheep in response to cloprostenol (125 $\mu \mathrm{g}$ i.m.)

\begin{tabular}{|c|c|c|c|c|c|c|}
\hline \multirow{2}{*}{$\begin{array}{l}\text { Sheep } \\
\text { No.* }\end{array}$} & \multirow{2}{*}{$\begin{array}{l}\text { Day after } \\
\text { oestrus }\end{array}$} & \multirow[b]{2}{*}{ Treatment } & \multicolumn{4}{|c|}{ Oxytocin concentrations $(\mathrm{pg} / \mathrm{ml})$ in plasma from: } \\
\hline & & & Ovarian vein & Utero-ovarian vein & Jugular vein & Artery \\
\hline \multirow[t]{4}{*}{$1 \dagger$} & \multirow[t]{4}{*}{11} & None & $220 \cdot 2(156 \cdot 5-257 \cdot 5)$ & $128 \cdot 2(82 \cdot 5-181 \cdot 0)$ & $34 \cdot 1(29 \cdot 2-42 \cdot 3)$ & $29 \cdot 6(21 \cdot 5-30 \cdot 5)$ \\
\hline & & & 3 & 3 & & \\
\hline & & Cloprostenol & $\begin{array}{c}11251 \cdot 0(5654- \\
19230)\end{array}$ & $1605 \cdot 6(1230-2580)$ & $110 \cdot 5(54 \cdot 9-183 \cdot 1)$ & $111 \cdot 2(32 \cdot 3-212 \cdot 3)$ \\
\hline & & & 4 & 6 & 8 & 7 \\
\hline \multirow[t]{2}{*}{$2 \dagger$} & \multirow[t]{2}{*}{12} & None & - & $\begin{array}{c}37 \cdot 0(19 \cdot 0-51 \cdot 0) \\
3\end{array}$ & $\begin{array}{c}27 \cdot 3(17 \cdot 0-34 \cdot 0) \\
3\end{array}$ & $\begin{array}{c}33 \cdot 0(17 \cdot 0-51 \cdot 0) \\
3\end{array}$ \\
\hline & & Cloprostenol & - & $\begin{array}{c}305 \cdot 9(203 \cdot 1-441 \cdot 4) \\
7\end{array}$ & $\begin{array}{c}78 \cdot 7(63 \cdot 0-106 \cdot 0) \\
7\end{array}$ & $\begin{array}{c}81 \cdot 0(22 \cdot 0-112 \cdot 0) \\
7\end{array}$ \\
\hline \multirow[t]{3}{*}{$3 \dagger$} & \multirow[t]{3}{*}{13} & None & $\begin{array}{c}206 \cdot 3(203 \cdot 0-212 \cdot 5) \\
3\end{array}$ & - & $\begin{array}{c}31 \cdot 7(23 \cdot 0-36 \cdot 0) \\
3\end{array}$ & $\begin{array}{c}36 \cdot 0(33 \cdot 0-42 \cdot 0) \\
3\end{array}$ \\
\hline & & Cloprostenol & $324 \cdot 7(219 \cdot 0-480 \cdot 0)$ & - & $39 \cdot 2(23 \cdot 9-50 \cdot 0)$ & $41 \cdot 7(33 \cdot 0-50 \cdot 0)$ \\
\hline & & & 6 & & 6 & 7 \\
\hline \multirow[t]{2}{*}{$4 \ddagger$} & \multirow[t]{2}{*}{$\begin{array}{l}\text { Ovari- } \\
\text { ectomized }\end{array}$} & None & - & - & $\begin{array}{c}28 \cdot 6(21 \cdot 8-34 \cdot 2) \\
3\end{array}$ & - \\
\hline & & Cloprostenol & - & - & $\begin{array}{c}23 \cdot 4(12 \cdot 0-35 \cdot 3) \\
8\end{array}$ & - \\
\hline \multirow[t]{2}{*}{$5 \ddagger$} & \multirow[t]{2}{*}{$\begin{array}{l}\text { Ovari- } \\
\text { ectomized }\end{array}$} & None & - & - & $\begin{array}{c}26 \cdot 6(21 \cdot 5-31 \cdot 8) \\
3\end{array}$ & - \\
\hline & & Cloprostenol & - & - & $\begin{array}{c}28 \cdot 0(14 \cdot 8-40 \cdot 9) \\
7\end{array}$ & - \\
\hline
\end{tabular}


Table 2. Concentrations of oxytocin in ovarian and uterine tissues of sheep before and $45 \mathrm{~min}$ after treatment with cloprostenol (125 $\mu \mathrm{g}$, i.m.)

\begin{tabular}{lcc}
\hline \multirow{2}{*}{\multicolumn{1}{c}{ Tissue }} & \multicolumn{2}{c}{ Oxytocin (ng/g wet wt) } \\
\cline { 2 - 3 } \multicolumn{1}{c}{ Untreated } & After cloprostenol \\
\hline Corpus luteum & $1714 \pm 37(3)$ & $39 \pm 16(5)$ \\
Remaining ovarian tissues & $<0.01(2)$ & $2.04 \pm 1 \cdot 18(4)$ \\
Non-luteal ovary & $0.64 \pm 0.39(4)$ & - \\
Anoestrous ovary & $<0.01(3)$ & - \\
Follicle & $<0.01(2)$ & - \\
Myometrium (Day 11-12) & $3.54(2)$ & - \\
Endometrium (Day 11-12) & $0.55(2)$ & - \\
\hline
\end{tabular}

Values are mean \pm s.e.m. for the no. of samples indicated in parentheses.

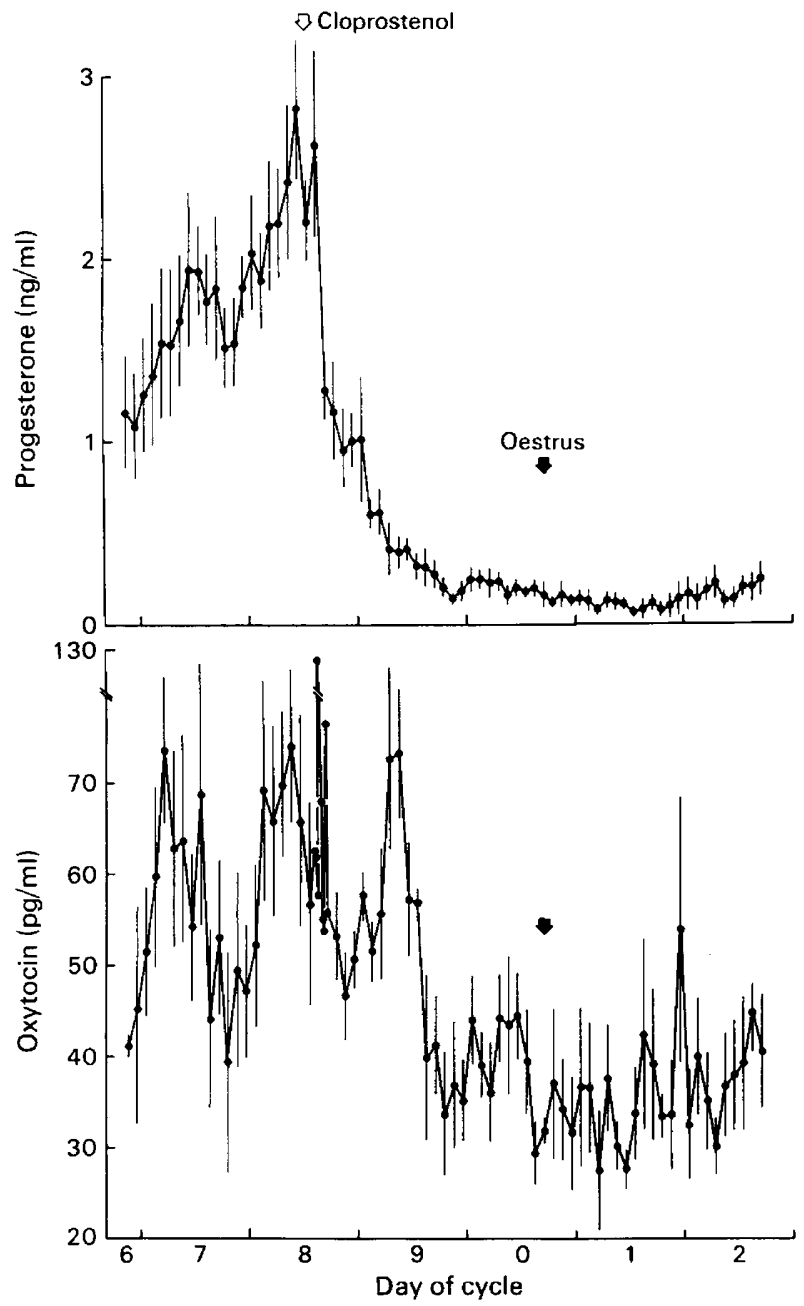

Text-fig. 3. Concentrations of oxytocin and progesterone in jugular venous plasma samples obtained from 4 ewes treated with cloprostenol $(125 \mu \mathrm{g}$, i.m.) on Day 8 after oestrus. Samples were obtained at 2-h intervals, except between $50 \mathrm{~min}$ before and $110 \mathrm{~min}$ after treatment, when they were taken every $20 \mathrm{~min}$. All animals displayed oestrus within $48 \mathrm{~h}$ after treatment. Values are mean \pm s.e.m. Values for progesterone obtained at $20_{\text {-min }}$ intervals are omitted for clarity; s.e.m. bars for these values are omitted from the oxytocin data. 


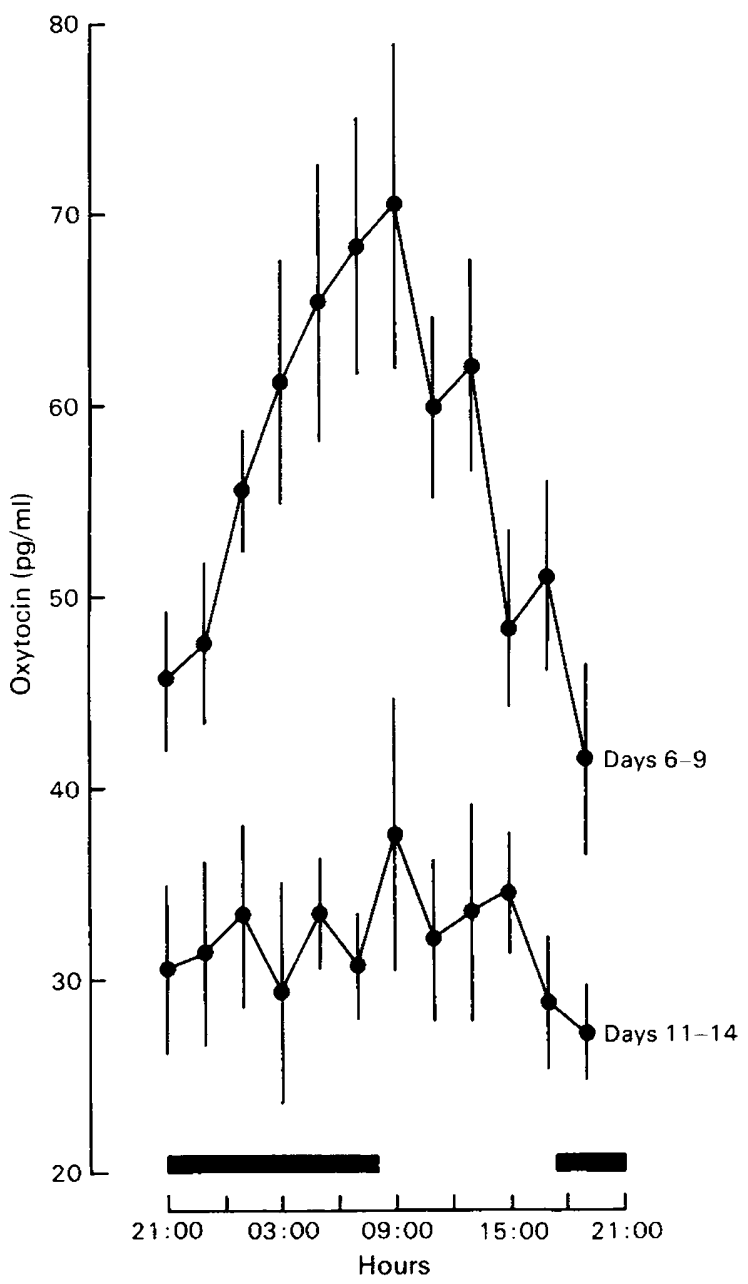

Text-fig. 4. Diurnal fluctuations in concentrations of oxytocin in jugular venous plasma; data of Text-figs 2 and 3 combined for Days 11-14 and 6-9 respectively. For each period, every point represents the mean \pm s.e.m. of 16 values ( 4 ewes $\times 4$ days). Both experiments were carried out in November and December 1981; the filled bar indicates hours of darkness.

Concentrations of oxytocin did not decline in parallel with those of progesterone, however, and basal levels were not reached until approximately $24 \mathrm{~h}$ after treatment. This experiment demonstrated the existence of a diurnal rhythm in circulating concentrations of oxytocin on Days 6-9 of the cycle which was absent on Days 11-14 (Text-fig. 4).

\section{Discussion}

Although it has not been purified and sequenced there is good evidence that the compound measured in the corpus luteum is oxytocin, including analysis by HPLC, milk ejection and uterine strip bioassays and radioimmunoassay (Wathes \& Swann, 1982). Qualitative analysis of the material in ovarian venous plasma is more difficult, as a result of the lower concentration at which it is present. Nonetheless the high specificity of the radioimmunoassay would indicate that the immunoactivity in ovarian venous plasma is also likely to be due to oxytocin, and this is supported 
by the presence in ovarian venous plasma of oxytocic activity as demonstrated by the rat milk ejection assay in vivo (A. P. F. Flint \& E. L. Sheldrick, unpublished observations).

The simultaneous changes in circulating concentrations of oxytocin and progesterone during the formation and regression of the corpus luteum (Text-fig. 1) confirm data previously obtained in more limited studies (Sheldrick \& Flint, 1981; Webb et al., 1981; Schams et al., 1982a) in demonstrating a precise parallelism between the secretion of these hormones. Within the limitations of the daily sampling regimen used there was no detectable increase in the plasma concentration of oxytocin at luteal regression. Changes in metabolic clearance did not contribute to the decline in oxytocin at oestrus (a finding which is consistent with the lack of effect of oestrogen on the half-life of oxytocin in ovariectomized rats; Sjöholm \& Ryden, 1967).

The concentration of oxytocin circulating at oestrus in the study illustrated in Text-fig. 1 (8-10 $\mathrm{pg} / \mathrm{ml}$ ) was approximately half that during the luteal phase $(18-21 \mathrm{pg} / \mathrm{ml})$, suggesting that half the oxytocin in the circulation is secreted by the corpus luteum. This may be an underestimate of the luteal contribution, however, since oxytocin was measured in the external jugular vein, which carries blood draining the pituitary (Hegedus \& Shackelford, 1965). Furthermore pituitary secretion of oxytocin may increase at oestrus; secretion in response to vaginal distension in sheep is enhanced by oestrogen (Roberts \& Share, 1969).

Production rates calculated from $\mathrm{MCR} \times$ circulating concentrations exceeded ovarian secretion rates determined from arterio-venous concentration differences; assuming an ovarian venous plasma flow of $4 \mathrm{ml} / \mathrm{min}$ (Short, McDonald \& Rowson, 1963; Mattner \& Thorburn, 1969) and taking typical arterial and venous oxytocin concentrations before treatment with cloprostenol of 29.6 and $220.2 \mathrm{pg} / \mathrm{ml}$ on Day 11 after oestrus (Ewe 1, Table1), the calculated ovarian production rate is $0.044 \mu \mathrm{g} / \mathrm{h}$, or only $8.3 \%$ of the production rate calculated from MCR $(29.6 \mathrm{pg} / \mathrm{ml} \times 300$ $\mathrm{ml} / \mathrm{min}=8880 \mathrm{pg} / \mathrm{min}=0.53 \mu \mathrm{g} / \mathrm{h}$ ). This discrepancy may be due to a number of factors. Anaesthesia probably decreases the MCR of oxytocin, by reducing hepatic blood flow, in a manner known to occur with other hormones (Bedford, Harrison \& Heap, 1973; but see Manunta \& Marongiu, 1961), and this would lead to the overestimation of production rates. Jugular venous oxytocin levels may be overestimated as a result of the recirculation of unidentified cross-reacting metabolites of oxytocin, and this would have the same effect. Furthermore ovarian secretion would be underestimated if a significant proportion of secreted oxytocin left the ovary in lymph. It is also possible that oxytocin is secreted by other as yet unidentified organs. A similar discrepancy between blood levels and secretion rates has been noted in the amounts of oxytocin appearing in ovarian venous blood after administration of cloprostenol; less than $20 \%$ of the oxytocin content of the corpus luteum can be accounted for in venous blood (Flint \& Sheldrick, 1982) under conditions in which $98 \%$ of luteal oxytocin is released (Table 2 ).

Although episodes of release of oxytocin were not detected when samples were taken daily, a more frequent sampling schedule did lead to the identification of surges of secretion (Text-fig. 2). In a high proportion of cases release of oxytocin and PGF- $2 \alpha$ (as reflected by circulating levels of the pulmonary metabolite 13,14-dihydro-15-keto-PGF-2 $\alpha$ ) occurred simultaneously. The surges of PGF- $2 \alpha$ metabolite in jugular venous plasma have been widely interpreted as reflecting uterine secretion of PGF- $2 \alpha$, since a similar episodic release pattern is seen in uterine venous blood with respect to PGF-2 $\alpha$ (Thorburn, Cox, Currie, Restall \& Schneider, 1973; Webb et al., 1981). The surges of PGF-2 $\alpha$ detected in this experiment were similar in frequency to those of neurophysin I in jugular venous plasma at luteal regression (Fairclough et al., 1980), and it seems probable that the same phenomenon was detected in both experiments. Fairclough et al. (1980) assumed that the surges of neurophysin indicated pituitary release of oxytocin, and that this led to the simultaneous episodes of release of PGF- $2 \alpha$. The demonstration that ovarian secretion of oxytocin is stimulated by a prostaglandin F-2 $\alpha$ analogue (Flint $\&$ Sheldrick, 1982) raises the possibility that this is in fact ovarian oxytocin, and that its appearance in blood results from, rather than causes, uterine secretion of PGF- $2 \alpha$. This would be consistent with the lack of detectable pituitary secretion of oxytocin in response to administration of a potent PGF- $2 \alpha$ analogue to conscious or anaesthetized 
ewes, which was shown to release ovarian oxytocin (Tables $1 \& 2$ ). However, it is not possible to rule out secretion of oxytocin by the pituitary in response to a stimulus other than PGF- $2 \alpha$.

Induction of luteal regression with cloprostenol caused a drop of approximately $50 \%$ in jugular venous concentrations of oxytocin, again suggesting that the ovary accounts for half the oxytocin in the jugular vein. Progesterone and oxytocin levels did not fall in parallel after cloprostenol, and although it induced rapid depletion of oxytocin from the corpus luteum (Table 2) cloprostenol did not immediately interrupt the diurnal rhythm in oxytocin levels. This raises the question whether the diurnal rhythm arises from changes in secretion of oxytocin by an organ other than the ovary, or by a cell in the corpus luteum distinct from that producing progesterone. The reason for the disappearance of the rhythm late in the cycle is unclear.

Active immunization against oxytocin leads to prolonged luteal function in sheep, and systemically administered oxytocin is to some extent luteolytic in the cow, sheep and goat (Armstrong \& Hansel, 1959; Milne, 1963; Cooke \& Knifton, 1981). In the cow the luteolytic effect of oxytocin is prevented by hysterectomy (Hansel \& Wagner, 1960). These observations suggest that the luteolytic action of oxytocin is exerted systemically, and the surges of oxytocin detected in jugular venous blood before luteal regression (Text-fig. 2) are consistent with such an action. The mechanism by which systemic oxytocin is luteolytic probably involves stimulation of uterine secretion of PGF-2 $\alpha$ (Flint \& Hillier, 1965; Horton \& Poyser, 1976) and the physiological significance of luteal secretion of oxytocin in response to uterine PGF- $2 \alpha$ may reside in the positive feedback loop this constitutes. Concentrations of oxytocin reached in the jugular vein after cloprostenol are comparable to those observed during episodes of secretion at luteal regression, and since cloprostenol almost completely depletes the corpus luteum of oxytocin (Table 2) each surge of oxytocin may represent release of all the oxytocin the corpus luteum contains. A decreasing level of oxytocin following complete release would tend to reduce uterine secretion of PGF- $2 \alpha$. Luteal secretion of oxytocin may therefore not only provide a means of amplifying the luteolytic signal and ensuring the rapid completion of luteal regression, but also lead to the cessation of each individual episode of secretion of PGF- $2 \alpha$.

\section{References}

Adashi, E.Y. \& Hsueh, A.J.W. (1981) Direct inhibition of testicular androgen biosynthesis revealing antigonadal activity of neurohypophysial hormones. Nature, Lond. 293, 650-652.

Armstrong, D.T. \& Hansel, W. (1959) Alteration of the bovine estrous cycle with oxytocin. J. Dairy Sci. 42, 533-542.

Bedford, C.A., Harrison, F.A. \& Heap, R.B. (1973) The kinetics of progesterone metabolism in the pregnant sheep. In The Endocrinology of Pregnancy and Parturition-Experimental Studies in the Sheep, pp. 83-93. Ed. C. G. Pierrepoint. Alpha Omega Alpha, Cardiff.

Cooke, R.G. \& Knifton, A. (1981) Oxytocin-induced oestrus in the goat. Theriogenology 16, 95-97.

Dawood, Y.M., Ylikorkala, O., Trivedi, D. \& Gupta, R. (1980) Oxytocin levels and disappearance rate and plasma follicle-stimulating hormone and luteinizing hormone after oxytocin infusion in men. J. Clin. Endocr. Metab. 50, 397-400.

Fabian, M., Forsling, M.L., Jones, J.J. \& Pryor, J.S. (1969) The clearance and antidiuretic potency of neurohypophyseal hormones in man, and their plasma binding and stability. J. Physiol., Lond. 204, 653-668.
Fairclough, R.J., Moore, L.G., McGowan, L.T., Petersen, A.J., Smith, J.F., Tervit, H.R. \& Watkins, W.B. (1980) Temporal relationships between plasma concentrations of 13,14-dihydro-15-keto-prostaglandin $\mathrm{F}$ and neurophysin $\mathrm{I} / \mathrm{II}$ around luteolysis in sheep. Prostaglandins 20, 199-208.

Flint, A.P.F. \& Hillier, K. (1975) Prostaglandins and reproductive processes in female sheep and goats. In Prostaglandins and Reproduction, pp. 271-308. Ed. S. M. M. Karim. MTP Press Lid, Lancaster.

Flint, A.P.F. \& Sheldrick, E.L. (1982) Ovarian secretion of oxytocin is stimulated by prostaglandin. Nature, Lond. 297, 587-588.

Hansel, W. \& Wagner, W.C. (1960) Luteal inhibition in the bovine as a result of oxytocin injections, uterine dilatation, and intrauterine infusions of seminal and preputial fluids. $J$. Dairy Sci. 43, 796-805.

Hegedus, S.A. \& Shackelford, R.T. (1965) A comparative-anatomical study of the cranio-cervical venous systems in mammals, with special reference to the dog: relationship of anatomy to measurements of cerebral blood flow. Am. J. Anat. 116, 375-386.

Horton, E.W. \& Poyser, N.L. (1976) Uterine luteolytic hormone: a physiological role for prostaglandin $\mathrm{F}_{2 \alpha}$. Physiol. Rev. 56, 595-651. 
Manunta, G. \& Marongiu, A. (1961) Inattivazione dell'oxitocina in vivo negli ovini. Boll. Soc. Ital. Biol. Sper. 37, 510-512.

Mattner, P.E. \& Thorburn, G.D. (1969) Ovarian blood flow in sheep during the oestrous cycle. $J$. Reprod. Fert. 19, 547-549.

McCracken, J.A., Schramm, W., Barcikowski, B. \& Wilson, L. (1981) The identification of prostaglandin $F_{2 \alpha}$ as a uterine luteolytic hormone in the sheep and the endocrine control of its synthesis. Acta vet. scand., Suppl. 77, 71-88.

Milne, J.A. (1963) Effects of oxytocin on the oestrous cycle of the ewe. Aust. vet. J. 39, 51-52.

Mitchell, M.D., Flint, A.P.F. \& Turnbull, A.C. (1975) Stimulation by oxytocin of prostaglandin $F$ levels in uterine venous effluent in pregnant and puerperal sheep. Prostaglandins 9, 47-56.

Mitchell, M.D., Flint, A.P.F. \& Turnbull, A.C. (1976) Plasma concentrations of 13,14-dihydro-15-ketoprostaglandin F during pregnancy in sheep. Prostaglandins 11, 319-329.

Roberts, J.S. \& Share, L. (1969) Effects of progesterone and estrogen on blood levels of oxytocin during vaginal distension. Endocrinology 84, 1076-1081.

Roberts, J.S., McCracken, J.A., Gavagan, J.E. \& Solofi, M.S. (1976) Oxytocin stimulated release of prostaglandin $F_{\alpha}$ from ovine endometrium in vitro: correlation with estrous cycle and oxytocin-receptor binding. Endocrinology 99, 1107-1114.

Schams, D., Lahlou-Kassi, A. \& Glatzel, P. (1982a) Oxytocin concentrations in peripheral blood during the oestrous cycle and after ovariectomy in two breeds of sheep with low and high fecundity. $J$. Endocr. 92, 9-13.

Schams, D., Prokopp, A. \& Schmidt-Adamopoulou, B. (1982b) The effect of active immunization against oxytocin on ovarian cyclicity in ewes. Acta endocr., Copenh., Suppl. 246, 7, Abstr.
Seldinger, S.I. (1953) Catheter replacement of the needle in percutaneous arteriography. Acta radiol. 39, 368376.

Sheldrick, E.L. \& Flint, A.P.F. (1981) Circulating concentrations of oxytocin during the estrous cycle and early pregnancy in sheep. Prostaglandins 22, 631636.

Sheldrick, E.L., Mitchell, M.D. \& Flint, A.P.F. (1980) Delayed luteal regression in ewes immunized against oxytocin. J. Reprod. Fert. 59, 37-42.

Short, R.V., McDonald, M.F. \& Rowson, L.E.A. (1963) Steroids in ovarian venous blood of ewes before and after gonadotrophic stimulation. $J$. Endocr. 26, 155167.

Sjöholm, I. \& Ryden, G. (1967) Half-life of oxytocin and lysine-vasopressin in blood of rat at different hormonal stages. Acta pharm. suecica 4, 23-30.

Tan, G.J.S., Tweedale, R. \& Biggs, J.S.G. (1981a) Oxytocin may have a role in the regulation of the human corpus luteum. J. Steroid Biochem. 14, xiii, Abstr.

Tan, G.J.S., Tweedale, R. \& Biggs, J.S.G. (1981b) Evidence for a direct effect of oxytocin on the bovine corpora lutea of early pregnancy. J. Steroid Biochem. 14, xvi, Abstr.

Thorburn, G.D., Cox, R.I., Currie, W.B., Restall, B.J. \& Schneider, W. (1973) PGF and progesterone concentrations in the utero-ovarian venous plasma of the ewe during the oestrous cycle and pregnancy. $J$. Reprod. Fert., Suppl. 18, 151-158.

Wathes, D.C. \& Swann, R. (1982) Is oxytocin an ovarian hormone? Nature, Lond. 297, 225-227.

Webb, R., Mitchell, M.D., Falconer, J. \& Robinson, J.S. (1981) Temporal relationships between peripheral plasma concentrations of oxytocin, progesterone and 13,14-dihydro-15-keto prostaglandin $\mathrm{F}_{2 \alpha}$ during the estrous cycle and early pregnancy in the ewe. Prostaglandins 22, 443-453.

Received 23 July 1982 